\title{
Hermeneutic comprehensions on female vulnerabilities belonging to the collective of lesbians, bisexuals, and transexuals
}

\author{
Compreensões hermenêuticas sobre as vulnerabilidades femininas \\ pertencentes ao coletivo de lésbicas, bissexuais e transexuais \\ Entendimientos hermenéuticos sobre las vulnerabilidades femeninas que \\ pertenecen al colectivo de lesbianas, bisexuales y transexuales
}

\section{Myllena Ferreira Peixoto ${ }^{a}$ Vander Monteiro da Conceição ${ }^{b}$ Silvio Eder Dias da Silva ${ }^{c}$ Manoel Antônio dos Santos ${ }^{\mathrm{d}}$ Lucila Castanheira Nascimento Jeferson Santos Araújo ${ }^{b}$}

How to cite this article: Peixoto MF, Conceição VM, Silva SED, Santos MA, Nascimento LC, Araújo JS. Hermeneutic comprehensions on female vulnerabilities belonging to the collective of lesbians, bisexuals, and transexuals Rev Gaúcha Enferm. 2021;42:e20200133. doi: https://doi.org/10.1590/19831447.2021.20200133
- Universidade Federal do Sul e Sudeste do Pará (UNIFESSPA), Faculdade de Saúde Coletiva. Marabá, Pará, Brasil.

- Universidade Federal da Fronteira Sul (UFFS), Curso de Enfermagem. Chapecó, Santa Catarina, Brasil.

Universidade Federal do Pará (UFPA), Faculdade de Enfermagem, Programa de Pós-graduaçăo em Enfermagem. Belém, Pará, Brasil.

${ }^{\star}$ Universidade de São Paulo (USP), Programa de Pós-Graduação em Psicologia. Ribeirão Preto, São Paulo, Brasil.

- Universidade de São Paulo (USP), Programa de Pós-Graduação Interunidades, Departamento de Enfermagem Materno-Infantil. Ribeirão Preto, São Paulo, Brasil.

\section{ABSTRACT}

Objective: To reveal the comprehension of women and health professionals about the feminine vulnerability belonging to the collective of lesbians, bisexuals, and transsexuals' women.

Method: Qualitative research, carried out from 0ctober 2018 to March 2019, in a Basic Health Unit located in Marabá - Pará, Brazil, using the hermeneutic-dialectic circle and inductive hermeneutic analysis. Five lesbians, bisexuals, and transsexuals' women and five health professionals participated, through interviews.

Results: Health care for women, as described by the participants, promoted social and programmatic vulnerabilities structured by taboos and preconception, which endorsed exclusive professional behaviors in the provision of specific care, which consequently amplified risks and threatened the quality of life of this population.

Conclusion: The dissemination of this evidence is configured as an indicator to support future decisions regarding priorities, application of resources and professional training in the care of lesbians, bisexuals and transsexuals' women.

Keywords: Sexual and gender minorities. Women. Health vulnerability. Public policy. Health personnel.

\section{RESUMO}

Objetivo: Desvelar a compreensão de mulheres e profissionais de saúde acerca da vulnerabilidade feminina pertencente ao coletivo de lésbicas, bissexuais e transexuais.

Método: Pesquisa qualitativa, realizada no período de outubro de 2018 a março de 2019, em uma Unidade Básica de Saúde localizada em Marabá - Pará, com o emprego do círculo hermenêutico-dialético e da análise hermenêutica indutiva. Participaram, por meio de entrevistas, cinco mulheres lésbicas, bissexuais e transexuais e cinco profissionais de saúde.

Resultados: A assistência em saúde às mulheres, como descrita pelos participantes, promoveu vulnerabilidades sociais e programáticas estruturadas por tabus e preconceitos, que endossaram comportamentos profissionais excludentes na oferta de cuidados específicos, os quais consequentemente amplificaram riscos e ameaçaram a qualidade de vida dessa população.

Conclusão: A divulgação dessas evidências configura-se como um indicador para subsidiar decisões futuras quanto a prioridades, aplicação de recursos e treinamento profissional na atenção às mulheres lésbicas, bissexuais e transexuais.

Palavras-chave: Minorias sexuais e de gênero. Mulheres. Vulnerabilidade em saúde. Política pública. Pessoal de saúde.

\section{RESUMEN}

Objetivo: Revelar la comprensión de las mujeres y los profesionales de la salud sobre la vulnerabilidad femenina perteneciente al colectivo de lesbianas, bisexuales y transexuales.

Método: Investigación cualitativa, realizada entre octubre de 2018 y marzo de 2019, en una Unidad Básica de Salud ubicada en Marabá - Pará, utilizando el círculo hermenéutico-dialéctico y el análisis hermenéutico inductivo. Participaron cinco mujeres LBT y cinco profesionales de la salud, a través de entrevistas.

Resultados: La atención médica para las mujeres, según lo descrito por los participantes, promovió vulnerabilidades sociales y programáticas estructurado por tabúes y preconcepción, que respaldaron comportamientos profesionales exclusivos en la prestación de atención específica, que en consecuencia amplificaron los riesgos y amenazaron la calidad de vida de esta población.

Conclusión: La difusión de esta evidencia está configurada como un indicador para apoyar futuras decisiones con respecto a prioridades, aplicación de recursos y capacitación profesional en el cuidado de mujeres lesbianas, bisexuales y transexuales. Palavras clave: Minorías sexuales y de género. Mujeres. Vulnerabilidad en salud. Política pública. Personal de salud. 


\section{口INTRODUCTION}

According to North American estimates ${ }^{(1)}$, lesbian, bisexual, and transsexual (LBT) women have worse health outcomes than heterosexual women. They fall ill mainly due to problems related to chronic, sexually transmitted diseases, illicit drug abuse, tobacco and alcohol abuse, and mental suffering specifically triggered by physical violence in the family, at work, and in public places ${ }^{(2)}$.

In recent years, evidence on the health care of this population has increased, but there are still many paths to be taken to achieve gender equity in health care $^{(3)}$. The practical applicability of this knowledge strengthens women's empowerment, as in the case of removing transsexuality from the list of diseases and mental disorders, access to sex reassignment surgery, and legal visibility in the health field ${ }^{(2-4)}$. In Brazil, the Ministry of Health published ordinance 2.836 of December 1, 2011, to institute the National Policy for Comprehensive Health Care of Lesbians, Gays, Bisexuals, Transvestites, and Transsexuals to promote comprehensive care for this population, eliminate discrimination and institutional prejudice, help reduce inequalities, and consolidate the Unified Health System ("SUS") as universal, comprehensive and equitable(4).

This policy is a significant advance in the rights to health care because it highlights the biological vulnerabilities of illness of the group and endorses the need for clinical care provided by health workers in the fight against diseases and in the planning of strategic actions, as access to health of this population is marked by obstacles that hinder full inclusion to care and assistance services ${ }^{(4)}$. However, there are operational gaps, especially with regard to its implementation, that include approaches focused on general vulnerabilities and sexually transmitted infections arising from unsafe sexual practices. Such approaches do not value actions and programs provided by health care services and professionals who envision comprehensive care and who are sensitive to vulnerabilities and other issues that go beyond the illness of the body.

The relationships established between these women and health workers exemplify this issue since, in many cases, they potentiate vulnerabilities related to assistance and care, which may lead to suffering, illness, and preventable death of this population ${ }^{(5)}$. Therefore, the vulnerabilities present in this process should be understood to strengthen care relationships ${ }^{(6)}$.

The concept of vulnerability has a broad and complex scope and accompanies the very concept of health care.
It is an analytical expression used to designate meanings to health-related phenomena, in addition to traditional behavioral approaches, as it can enhance the success of clinical actions and the resolvability of care provided to this population ${ }^{(7)}$. Moreover, the experience of vulnerability is related to the following three dimensions: the individual, with respect to the degree of specific knowledge of the subject and their prevention actions, when at risk; the program, in terms of health services and the public in general, civil society organizations, and private enterprises; and the social, which deals with social factors that determine access to services, commodities, information, as well as the economy, public policies, and relations between gender, among others ${ }^{(8)}$.

An integrative literature review ${ }^{(9)}$, composed of 41 primary studies selected from the databases PubMed ${ }^{\circledR}$, Latin American literature in Health Sciences (LILACS), and Scientific Electronic Library Online (SciELO), analyzed the Brazilian and international literature published from 2007 to 2018 on the quality of health care to the population of lesbians, gays, bisexuals, transvestites, and transsexuals (LGBT). The results corroborated and revealed that the relationships between users, health workers, and organizations are not always harmonious and the LGBT population also faces prejudice, violence, and discrimination in health care systems, thus placing them in a vulnerable situation. However, the vulnerability described is related to the social determinants of health care for the group and the review does not reveal whether the concept of vulnerability affects the health promotion and disease prevention practices for this population.

In the health care practice, researchers seek to understand their reality from theoretical concepts and their applicability in the process of health and disease. Thus, it is essential to identify and characterize the vulnerabilities ${ }^{(6)}$ experienced by women and health workers during care and, subsequently, develop individual and collective care actions according to the needs faced. Interpretative methodologies, such as the one developed in this study, provide a better understanding of the experienced phenomenon since they focus on the subjectivity of the experiences in depth, which enhances the clinical applicability of the results.

Therefore, this research was guided by the following question: What knowledge do women and health professionals have regarding the vulnerability of lesbian, bisexual, and transsexual women? To answer the question, the aim was to reveal how women and health workers understand the vulnerability of women belonging to the collective of lesbians, bisexuals, and transsexuals. 


\section{METHOD}

This is a qualitative study, operationalized by the interpretative method of the hermeneutic-dialectical circle $(\mathrm{HDC})^{(10)}$, based on the collective construction of knowledge with the following four stages: simultaneous data collection and analysis; identification of essential factors; synthesis of information; and condensation and analysis of data of each interviewed group. The HDC enables interaction between those being interviewed and/or between the interviewees and the researcher and allows the subjects to perform a cyclic construction of knowledge, by interpreting reality and making sense of the experienced phenomena ${ }^{(10)}$. It should be noted that the consolidated criteria for reporting qualitative research (COREQ) checklist was used to conduct this study (11).

The study scenario was a primary care unit located in the city of Marabá, state of Pará, Brazil, where 14 health workers and 8 women were invited to participate using convenience, non-probability sampling. This unit was chosen because of the service it provides in the region, with consultations and monitoring of public policy implementation, and because it is a unit of reference in the defense of the rights of LGBT women.

The inclusion criteria were women who identified themselves as members of the LBT group, regardless of education level and socioeconomic status, and who used the public health service; health workers and secretary, and primary care workers who provided care to LBT women or worked in service management. After this stage, 9 professionals and 3 women did not meet the established criteria. Thus, two groups participated in the study, one consisting of 5 women and the other of 5 health workers (including 1 health secretary), distributed as illustrated in Figure 1. The participation of the secretary of health is justified because he was involved in and responsible for defining the strategies and implementation of the LGBT policy in health care services, as in the scenario unit of this study.

Data were collected by the principal investigator individually with each participant from October 2018 to March 2019, through in-depth interviews guided by the research script, and recorded in digital audio device, with an average duration of 50 minutes. The interviews were previously scheduled and conducted in a private room at the health service premises.

The research script contained the following questions for the women: Do you consider yourself a vulnerable person?
Have you ever suffered any kind of complication/aggravation at the health service? What does the National Policy for Comprehensive Health Care of Lesbians, Gays, Bisexuals, Transvestites, and Transsexuals mean to you? For health workers, the questions were: Do you consider LGBT women vulnerable? Do you use the principles of the National Policy for Comprehensive Health Care of Lesbians, Gays, Bisexuals, Transvestites, and Transsexuals in your work? What strategies and actions aimed at the health care of the LGBT population are developed in your workplace? It is noteworthy that, on average, two to three meetings were held with each participant and that, as the woman or the health workers presented their testimonies, other questions were created to gain further insight into the studied phenomenon.

Hermeneutics, as the art of interpretation, and dialectics, as the art of dialogue, allowed researchers in the field to carry out a continuous back and forth movement in the construction and reconstruction of texts derived from the experiences shared during the interviews ${ }^{(10,12)}$.

As illustrated in Figure 1, HDC was managed according to the formation of three concentric circles. In the first, the respondents were interviewed and coded by replacing their real names with fictitious names to ensure their anonymity. For the graphic illustration of the figure, the fictitious names of the participants were replaced by al phanumeric codes (for women, M1 for Roberta, M2 for Kátia Flávia, M3 for Thaís, M4 for Ana and M5 for Júlia; for the health workers, the codes were P1 for Márcia, P2 for Guilherme, P3 for Matias, P4 for Isadora, and P5 for Carlos). Subsequently, in the second circle, the syntheses provided by the testimonies collected during the larger circle process were constructed, that is, C1 represented the synthesis constructed by M1/P1 after presenting their testimonies; $\mathrm{C} 2$ represented the synthesis constructed by M2/P2 after presenting their testimonies and having access to the synthesis $\mathrm{C} 1$; sequentially, $\mathrm{C} 3$ represented the synthesis constructed by M3/P3 after presenting their testimony and having access to the synthesis $\mathrm{C} 2$ and so on, until the last interviewee.

Once the objective of the study was reached, when no new information was added to the prepared texts, a final meeting was held with the respondents. In this meeting, the ideas were discussed to reach a systematized consensus and present the shared experiences by the group in a narrative text format (primary text). Based on this text, the process of inductive hermeneutic analysis began, according to the 


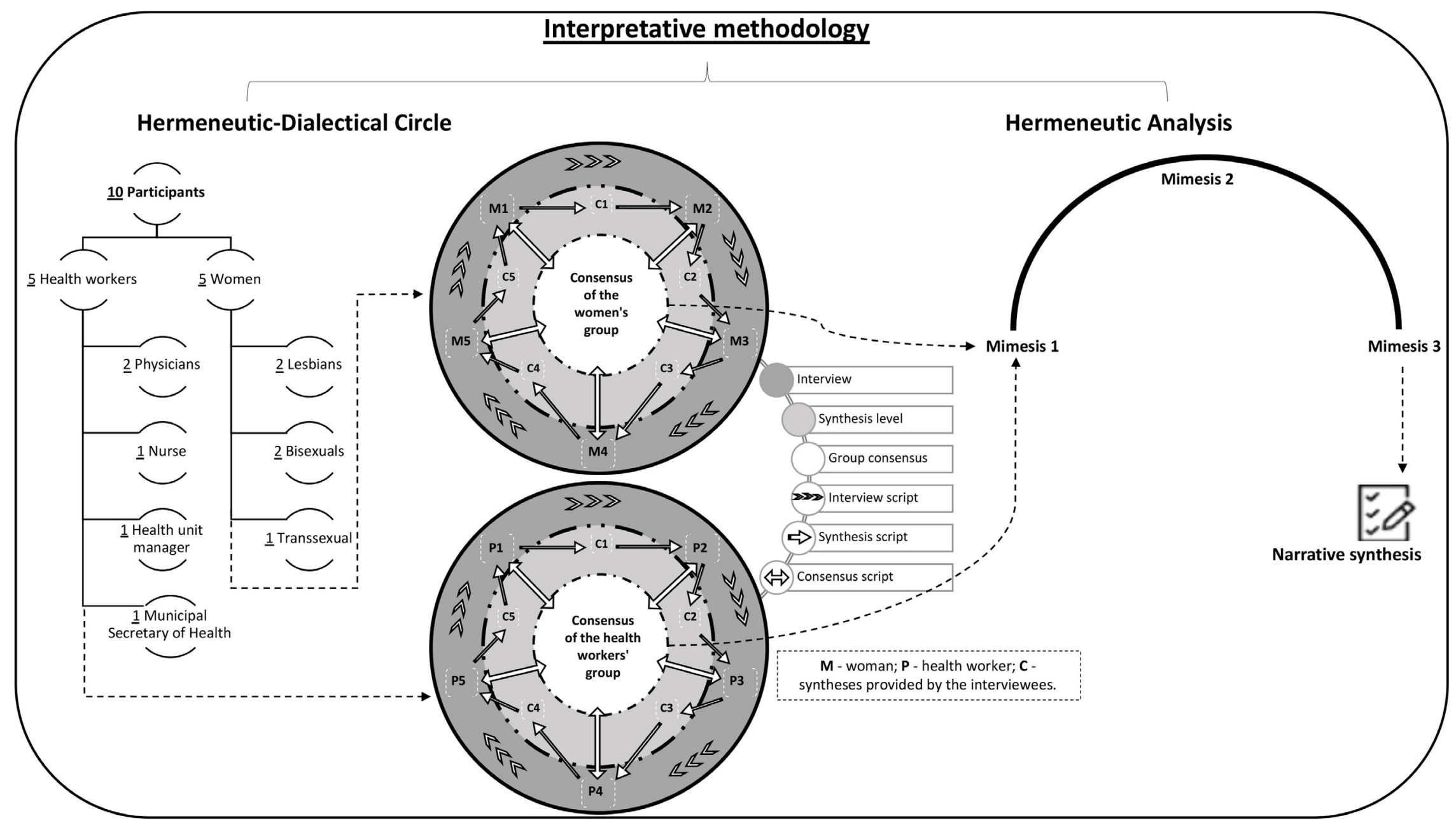

Figure 1 - Methodological operationalization of the study. Marabá, PA, Brazil (2019) Source: Authors, 2019. 
assumptions of Paul Ricoeur ${ }^{(12)}$. In this stage, as illustrated in Figure 1, the experiences were interpreted through a comprehensive description of the studied phenomenon. The process started with a naive understanding, based on analysis of the primary text (mimesis 1 ), and proceeded to the intermediate understanding, in which the researchers sought to interpret the parts and the whole in the context of the respondents regarding the studied phenomenon (mimesis 2). It ended with wise understanding (mimesis 3), in which the researchers performed the fusion of horizons, a process that permeated the dialogical and dialectical. Thus, the researchers described, explained, and interpreted the discourses with understanding and otherness, giving rise to a secondary narrative text that corresponds to the shared experiences, resulting from the interaction between the researcher, the speakers, and the studied phenomenon ${ }^{(12)}$.

In order to give meaning to the lived and the narrated, in addition to elucidating the interpretation on a theoretical basis, two narrative syntheses were prepared and named 'Vulnerabilities in resistant women' and 'Dilemmas in the health care of lesbian, bisexual, and transexual women'.

The ethical principles, as determined by resolutions 466/12 and 510/16 of the National Health Council, were met at all stages of the study. The study was approved by the Ethics Committee in Research with Human Beings of the Federal University of Pará, under CAAE number 94866418.0.0000.0018 and opinion 2,929,216. The objectives of the study and the importance of their participation were explained to the participants and those who agreed signed an informed consent statement.

\section{RESULTS}

Among the study participants, five women identified themselves as female, and among the health workers, five were male. Average ages were 25 years old in the women's group and 29 years old in the health workers' group. As for marital status, nine declared they were single. Seven reported having some religious belief and had complete higher education. With regard to sexual orientation, in the group of LBT women, two identify as lesbian, two as bisexual, and one as transsexual. In the group of health workers, one identified as gay and four as heterosexual.
In order to elucidate the interpretative process of the information, the main defining elements of the vulnerabilities analyzed were highlighted in the narratives (prejudice, discrimination, inequality, inequality, social exclusion, unpreparedness of health workers, negligence, and inefficiency in the implementation of public policies).

\section{Vulnerabilities in resilient women}

Although some consider being LBT as natural and normal, I think that being a lesbian, bisexual, or transsexual woman is a daily challenge. It is a daily struggle to find your place in society, it is resisting against the prejudice and invisibility inside and outside the LGBT community. It is to be constantly fighting to overcome standards imposed by the sexist and patriarchal society in which we live. For some, such as trans women, being LBT is also about finding a place where they are well received, because there, as with others like them, they see their identity being recognized and respected. (Kátia Flávia and Roberta)

The fact that we are women already makes us vulnerable, by associating issues such as color, sexuality, non-performance of femininity, among others. These issues only increase this feeling of vulnerability that we experience daily [...]. For us, LBT women, the feeling of vulnerability is present at all times, but within the health system, it seems very evident, because no one is prepared to receive us in the right way, starting from the penetrating and judgmental looks we receive when seeking the service to the surprise reactions with which health workers treat us. The feeling we get from them is that we are strange, abnormal, people who defy nature or who are not connected to who they really are. However, if we have money, we run from the SUS [Unified Health System] and it seems that in other scenarios, this is more camouflaged, we partially distance ourselves from this vulnerability, which brings us a slight and fleeting sense of security. (Roberta, Ana, and Kátia Flávia) 
Public health services, in theory, should be easily accessible places where lesbian, bisexual, and transsexual women should feel at ease, safe, and welcomed. A reality very far from the one we experience because, by identifying ourselves as LBT to health workers and in the system, we subject ourselves to several situations that a heterosexual woman does not experience. They make us feel small, as if we are less than other women, just because of who we are. (Julia and Anne)

At all times, we come across health workers who want to assist us with the same precepts as heterosexual women. Colleagues have experienced situations in which, when identifying themselves as lesbian or bisexual, the health workers interrupted the consultation and admitted that he did not know how to attend them or simply ignored what they said and continued using a procedure for heterosexual users, including prescribing specific and highly invasive examinations of their organs that exposed them to unpleasant situations. Certainly, not all of us go through these things, and we know women who have never experienced them, but there is no denying that most of US, LBT, have already been subjected to something like this. But we keep our heads high! (Thaís, Roberta, Kátia Flávia and Júlia)

For US, LBT women, the fact that we identify as such, makes us more vulnerable and also more resilient, as we are reaffirming our existence and needs. Our identification as a lesbian, transsexual, or bisexual woman is our way of showing the health system and workers that we exist and that we need care according to our demands and specificities, and not from the common standards of heteronormativity. Identifying yourself is al ways very important, but we understand the other side, the side of those who prefer not to tell health workers their sexual orientation because they do not want to go through the awkward situations during the consultations $o r$, as in the case of an acquaintance who, when she goes with her mother, prefers not to say anything because the mother does not accept her sexual orientation well. We are the same, even in different situations! (Júlia, Ana, and Thaís)
Like most women, we need the health services for prevention, emergencies, and health rehabilitation. The public health service is the most widely used because we have the right to be there, but when we do not feel well treated and in case of emergency, we use the private system. (Thais, Julia, and Ana)

We cannot deny that the obstacles we face when seeking health services are very recurrent. Places that should be receptive and provide care show total unpreparedness and prejudice towards many of us. The National Policy for Comprehensive Health Care of Lesbians, Gays, Bisexuals, Transvestites, and Transsexuals is a great achievement for us because it recognizes the needs and difficulties that our collective faces in health systems; it also gives us a sense of greater security when seeking care. (Roberta and Kátia Flávia)

But not everything is roses! The need to enforce this policy so that the health system and workers are more capable of providing care is remarkable. There is still much to be done for our care to effectively improve, such as the implementation of the policy in all municipalities, the creation of a care network that actually meets the needs of LBT women, and professional training, which is undoubtedly the biggest challenge. One day, who knows! (Roberta, Kátia Flávia, Thaís, Ana, and Júlia)

Dilemmas for the health care of lesbian, bisexual, and transsexual women

As health workers, we understand that women are naturally vulnerable, as there is a social and cultural issue in which women are considered more fragile than men. When we think about these issues for LBT women, this vulnerability becomes even greater due to factors that they face to get care, such as the prejudice in not recognizing them as belonging to these places since they are not entirely women! Many of them, depending on their appearance, are immediately associated as carriers of sexually transmitted infections, with the use of alcohol and other drugs. However, while many of us see them with 
these vulnerabilities, others don't see them that way. (Marcia, Guilherme, Matias, and Carlos)

We realize that there is still a great difficulty in providing care to this population, specifically lesbian, bisexual, and transsexual women, because often their sexual orientation or gender identity is not identified, which ends up hindering our care because we do not know how to treat them. (William, Matthias, and Charles)

It is not easy to assist them because we are not prepared to deal with the needs of this population; we do not receive professional training in this regard in college and when we are in the job market, we also do not have knowledge of the subject. No one talks about them, no one talks about how we should provide care for them, and no one seems to do anything to change that! An example is the National Policy for Comprehensive Health Care of Lesbians, Gays, Bisexuals, Transvestites, and Transsexuals that most of us are unaware of, even though it was launched almost 10 years ago. (Isadora, Marcia, Guilherme, and Matias)

From a professional standpoint, we understand that the existence of this policy reinforces the rights of the LGBT population because it points out needs that already existed, but were neglected. We see this health policy as an ally, as one more way to show society, which is largely prejudiced, that the struggle of LBT women must be perceived more and more. However, it seems that it only exists on paper, because in real life it is ignored, there is no program, no campaign, nothing! (William and Matthias)

Although some of us think that this policy brings some benefits, others totally disagree, believing it does not have great representativeness for the LBT population because, in their opinion, the policy can generate greater exclusion of this population since, by following the precepts and guidelines of the policy, LBT women would be receiving different treatment from the rest of the population. Treating them as different would only reinforce the idea that they are not equal to other women. If we do not empower ourselves, these differences in our vision as professionals will only reinforce challenges for the full implementation of the policy to the needs of this collective. (Isadora, Marcia, and Guilherme)

The National Comprehensive Care Policy of the LGBT population can potentially become a resistant policy, as much as the national health policies of women, children, the elderly, among others, so we see the constant need for reformulations and adaptations in the implementation of this policy to meet the real needs of its population. An example is the differences in our national geography, the northern woman is not the same southern woman. So we have to look within their specificity, within their geography, and make the community understand that. (Guilherme and Carlos) We understand that the biggest point that needs to be reviewed is professional training for active and future workers, to ensure they interpret and understand the policy so it stops being theory and comes alive in practice because currently, it seems to be dormant. In this way, we become stronger and we can clear many paths, demystifying thoughts for the policy to gain strength and increasingly protect these vulnerable women. (Carlos)

\section{DISCUSSION}

To ensure the complexity of LBT narratives in the health field is viewed comprehensively, it is necessary to elucidate that the vulnerabilities were related to a theoretical perspective, in which gender and femininity maintain a close relationship with the health care issues faced by women ${ }^{(3,6)}$. Because gender is a constructive element of feminist relations, it is presented in the studied context as a guide to signify the power relations exerted between women and health workers ${ }^{(4)}$. In this field of production, female vulnerabilities are generalized ${ }^{(5)}$ and influence health care ${ }^{(3)}$.

The narratives of the studied groups provide an explanation derived from practical wisdom about how vulnerabilities are structured in this context. For the women, this arises from the perception of how their relations with society are conducted (surrounded by taboos and prejudices), while, the health workers stress how society and health services recognize women during the provision of care (people who do not fit into a specific clinical standard of care already 
established binarily). In both contexts, it is possible to interpret the recurrence of a plot that hierarchizes care practices, in which heteronormative issues are the central axis of discourse, while the other practices developed by women are subordinate to this dominant model. Thus, the health care in these relationships is and creates vulnerabilities.

Based on this perspective, the narratives highlight a hegemonic social imaginary, which places LBT women as bearers of an individual vulnerability, as if the fact they exist naturally makes them vulnerable. However, this discourse is paradoxical since this perception of vulnerability is based on genetic, biological, and physiological aspects that increase the risk of physical disease, and not from a cultural perspective ${ }^{(8)}$. The expression of this vulnerability, as exemplified in another study ${ }^{(3)}$, has irreversible consequences for women, as in cases of prostate cancer (in transsexual women) and breast and cervical cancer, that are aggravated due to low use of health services, thus leading to preventable deaths in this population.

What vulnerability are we talking about? According to the female narratives, individuals belonging to the LBT collective get sick like any other person because the illnesses of their bodies do not specify their gender, but establish obstacles in the defense of their identities as LBT. Therefore, the vulnerabilities highlighted in their statements correspond to individual factors and, above all, to social vulnerabilities ${ }^{(13)}$ since the conditions imposed on the group of women are outside a zone of integration of biological exclusivity - in this case, related to interference of the cultural context.

Women experienced stigmas and specific prejudices related to their stereotypes, the defense of their identities as female, the prejudiced interpretation that they are "carriers" of diseases such as HIV/AIDS, and the tone of their skin, among other realities accentuated when compared with heterosexual and white women.

Researcher ${ }^{(1,5)}$ endorse this prerogative inferring that several factors affect the biological health of women, such as geographical and territorial aspects, which are outside the individual control of a person but which potentiate experiences of vulnerability. Exploring and reflecting on these determinants and the disparities that accompany them, as well as policies established to address equity, should be encouraged by health workers in the pursuit of comprehensive care. However, at present, it is observed that this movement is marginalized and deprived of implantation strategies that foster extended clinical competence.
Surrounded by the daily challenge of overcoming anxiety, fear, and the expectation of rejection resulting from homophobia in health care centers, women demand specific care and seek professional assistance. Evidence ${ }^{(3,6,9)}$ supports that, during this search, they face the unpreparedness of doctors, nurses, and managers to assist them, which only increases their vulnerabilities in primary care. Services do not recognize them as women connected to each other, regardless of their gender identities and sexual orientations, but rather as women devoid of hegemonically identified heteronormative labels. This perception causes them to receive care that is disjointed, exclusionary, and not individualized in relation to their real health care needs.

In this regard, risk exposure, in turn, can trigger adverse health outcomes and, consequently, affect their quality of life ${ }^{(14)}$, as, for LBT women, defending the legitimacy of their identities represents a link that connects their self with the world, by building it and humanizing it; therefore, identifying themselves as such is an act of resistance and reaffirmation of their existence. Researchers ${ }^{(4)}$ state that this characteristic represents a search for the validation of their health care rights legally acquired and operationalized by public policies.

Health professionals also recognize them as vulnerable; however, they associate them with susceptibility to certain diseases or mental disorders (sexually transmitted infections, alcoholism, and drug use) and access to health care services. For the health workers, the multiple gender identities defended when assisting the LBT community in primary care are hinder the provision of integrated care since these women are disconnected from the formative/curricular knowledge experienced in their professions. Thus, in light of the new that emerges in contact with a gender-specific body, which, for now, is viewed from the binary standpoint, idealized by health workers as male or female and labeled as belonging to a heteronormative category, many feel disqualified or lacking the knowledge that justifies specific behaviors toward this population. From this perspective, a programmatic vulnerability is theoretically articulated, as the way health policies, workers, and services are coordinated directly influences health outcomes in primary care ${ }^{(8)}$.

Doctors and nurses from North American countries ${ }^{(3)}$ and Europe ${ }^{(15)}$ also share the barriers to the comprehensiveness of their care and point out that the current status of teaching and training specific to clinical competence for LBT care is insufficient and incapable of supporting conducts needed to reduce disparities in health care. According to them, there is a shortage of didactic and clinical strategies 
to incorporate this content into the undergraduate and graduate curricula, which would ensure care is provided in a culturally competent way.

In Brazil, health workers do not receive specific training for the demands of this population and lack educational interventions that demonstrate potential knowledge to improve inclusive attitudes for LGBT users. It is necessary to develop inclusive strategies, make changes to the curriculum, expand the clinical beyond the biomedical, and change paradigms, so that the vulnerabilities of women are overcome before their multiple gender identities.

The National Policy for Comprehensive Health Care of Lesbians, Gays, Bisexuals, Transvestites, and Transsexuals also demands some strategic specificities (offering sensitive and individualized care) to ensure its implementation is increasingly consistent with the reality of women in primary care, as pointed out by the professionals. Certainly, this is a field that needs to be expanded in the search for gender equity and respect for femininity.

The narratives show progress towards the health issues of LBT women since they have gained rights and legal visibility. However, it is necessary to clarify that the two groups investigated have different conceptions regarding vulnerabilities. While for the women they are anchored in a social field (defense of their identities and sexualities), for the health workers, they are in the programmatic field (certain limitations of the services and in the absence of continuing education and training). Although these conceptions are different, both recognize the achievements and potential that the National Policy for Comprehensive Health Care of Lesbians, Gays, Bisexuals, Transvestites, and Transsexuals represents in terms of confronting these vulnerabilities. Researchers ${ }^{(16)}$ who defend this perspective highlight that, with the implementation of this policy, the legal insertion of women in health prevention and promotion services increases, thus guaranteeing them access to rights and ensuring state duties for their execution.

However, the implementation of legal devices alone is not enough nor is it synonymous with guaranteed care when confronting the many social and programmatic vulnerabilities that affect the LBT population. As revealed in other studies ${ }^{(9)}$, women and health workers need special attention regarding the promotion of health practices because, as clarified by women, health services are still exclusionary, difficult to access, and provided by professionals who lack awareness of their gender and sexual orientation issues. In turn, the investigated health workers base their explanations on the lack of specific training, health programs, more objective strategies for implementing this policy in care and in care environments in order to elucidate the particularities of this group since, although the existence of demands is recognized, investments for the development of specific skills and abilities to assist them are still limited.

These results agree with those obtained in other studies ${ }^{(4,16)}$, which also endorse these findings by demonstrating that the health services are only found in the field of health policies for the LGBT population in theory. Although most resources and efforts have been directed toward reducing the disparities in women's care, the results are still unsatisfactory from the point of view of their implementation. In the field of cultural education and training, health workers lack the necessary skills needed for clinical evaluations and humanized, individualized, and ethical assistance for the LGBT population ${ }^{(17-18)}$.

The social and programmatic vulnerabilities, associated with the structural, cultural, and organizational obstacles faced by the LGBT community in health care, impose symbolic and moral barriers for the health promotion of this population ${ }^{(13-14)}$. Thus, the knowledge and the practices that are associated with these vulnerabilities, as well as how the National Policy for Comprehensive Health Care of Lesbians, Gays, Bisexuals, Transvestites, and Transsexuals is implemented in the group under study have implications for the promotion of health-related human rights violations, the reduction in the frequency of attendance, the choice to not seek health care, and the worsening of the self-care deficit, resulting in an increase in the vulnerability of all members of the LBT population.

Addressing the vulnerabilities highlighted in this study and defending the effective implementation of the health rights acquired by LBT women mean that the respect for citizenship and the dignity of the human being must be guaranteed, thus promoting the principles of equity and humanization in health care. Planned actions are urgently needed to strengthen the engagement of health workers, such as training and strategies for implementing the policy and strengthening protection ties to this community, which is subjected to systematic social exclusion.

Studies on LBT women and their vulnerabilities enable further discussions in health care, especially with regard to individual and collective attitudes and practices of doctors and nurses that increasingly qualify care, which is not yet found in the national and international literature. Thus, the 
results of the present study contribute to health care as an indicator for the implementation of measures that prioritize the knowledge management of health workers and help them recognize these vulnerabilities in care relationships. This is certainly a first step to trigger corrective and improvement actions in the care provided to this population.

However, in view of the results presented and the investigated context, the fact that the study was conducted in a single scenario is considered a limitation. Another limitation is the absence of a debate regarding race, which is a factor the increases vulnerabilities. Race was not identified in the research possibly because the LBT women did not identify themselves as black, brown, or indigenous, among others, which could have extended the understanding produced by this study. Therefore, new studies in other fields could analyze whether these vulnerabilities are found in other health care contexts, as this study was conducted locally, in Brazil.

\section{Q CONCLUSION}

The interpretative method of the hermeneutic-dialectical circle was adopted to identify how women and health workers perceive the vulnerabilities that lesbian, bisexual, and transsexual women face in health care. The women view the health services as exclusionary and not individualized to their particular needs. In contrast, the health workers recognize the barriers in the provision of care, especially regarding the implementation of public policies. These conditions produce vulnerabilities and increase health risks with implications for these vulnerable women, such as the violation of human rights, reduced attendance, and, consequently, the decision to not seek medical care.

In this regard, the shared knowledge reveals obstacles to the implementation of the National Policy for Comprehensive Health Care of Lesbians, Gays, Bisexuals, Transvestites, and Transsexuals in the practice field and highlights the absence of professional training, specific health programs, and culturally sensitive care strategies. To face this problem, elements of the subjective experience of health workers and lesbian, bisexual, and transsexual women should be incorporated in strategic health care planning for this population.

These data may support the future decisions of nurses and healthcare managers regarding priorities, application of resources, and professional training in the care of lesbian, bisexual, and transsexual women. Moreover, it is essential to broaden this debate since women's vulnerabilities related to the implementation of the National Policy for Comprehensive Health Care of Lesbians, Gays, Bisexuals, Transvestites, and Transsexuals are present and, when not understood, can compromise the quality of offered care.

\section{REFERENCES}

1. Health equity. Health Aff. 2018;37(3):344-5. doi: https://doi.org/10.1377/ hlthaff.2017.1519

2. Cardoso MR, Ferro LF. Saúde e população LGBT: demandas e especificidades em questão. Psicol Cienc Prof. 2012;32(3):552-63. doi: https://doi.org/10.1590/ S1414-98932012000300003

3. Bonvicini KA. LGBT healthcare disparities: What progress have we made? Patient Educ Couns. 2017;100(12):2357-61. doi: https://doi.org/10.1016/j. pec.2017.06.003

4. Popadiuk GS, Oliveira DC, Signorelli MC. The National Policy for Comprehensive Health Care of Lesbians, Gays, Bisexuals, Transvestites, and Transsexuals (LGBT) and access to the Sex Reassignment Process in the Brazilian Unified Health System (SUS): progress and challenges. Ciênc Saúde Coletiva. 2017;22(5):150920. doi: https://doi.org/10.1590/1413-81232017225.32782016

5. Keuroghlian AS, Ard KL, Makadon HJ. Advancing health equity for lesbian, gay, bisexual and transgender (LGBT) people through sexual health education and LGBT-affirming health care environments. Sexual Health. 2017;14(1):119-22. doi: https://doi.org/10.1071/SH16145

6. Malagón-Oviedo RA, Czeresnia D. 0 conceito de vulnerabilidade e seu caráter biossocial. Interface (Botucatu). 2015;19(53):237-50. doi: https://doi. org/10.1590/1807-57622014.0436

7. Boldt J. The concept of vulnerability in medical ethics and philosophy. Philos Ethics Humanit Med. 2019;14:6. doi: https://doi.org/10.1186/ s13010-019-0075-6

8. Bolina AF, Rodrigues RA, Tavares DM, Haas VJ. Factors associated with the social, individual and programmatic vulnerability of older adults living at home. Rev Esc Enferm USP. 2019;53:e0342. doi: https://doi.org/10.1590/ s1980-220x2017050103429

9. FerreiraBO,BonanC.Openingtheclosets ofaccessandquality:anintegrativereview on the health of LGBTT populations. Ciênc Saúde Coletiva. 2020;25(5):1765-78. doi: https://doi.org/10.1590/1413-81232020255.34492019

10. Oliveira MM. Experiências exitosas com sequências didáticas interativas. Recife: EDUFPRE; 2017.

11. Tong A, Sainsbury P, Craig J. Consolidated criteria for reporting qualitative research (COREQ): a 32-item checklist for interviews and focus groups. Int J Qual Health Care. 2007;19(6):349-57. doi: https://doi.org/10.1093/intahc/mzm042

12. Missel $M$, Birkelund R. Ricoeur's narrative philosophy: a source of inspiration in critical hermeneutic health research. Nurs Philos. 2019;14:e12254. doi: https:// doi.org/10.1111/nup.12254 
13. Kröner SM, Beedholm K. How discourses of social vulnerability can influence nurse-patient interactions: A Foucaultian analysis. Nurs Inq. 2019;18:e12309. doi: https://doi.org/10.1111/nin.12309

14. Jennings L, Barcelos C, McWilliams C, Malecki K. Inequalities in lesbian, gay, bisexual, and transgender (LGBT) health and health care access and utilization in Wisconsin. Prev Med Rep. 2019;14:100864. doi: https://doi.org/10.1016/j. pmedr.2019.100864

15. Donisi V, Amaddeo F, Zakrzewska K, Farinella F, Davis R, Gios L, et al. Training healthcare professionals in LGBTI cultural competencies: exploratory findings from the Health4LGBTI pilot project. Patient Educ Couns. 2019;103(5):978-87. doi: https://doi.org/10.1016/j.pec.2019.12.007
16. Belém JM, Alves MJ, Pereira EV, Moreira FT, Quirino GS, Albuquerque GA. Health care for lesbian, gay, bissexual, transvestite and transgender individuals in the Family Health Strategy. Rev Baiana Enferm. 2018;32:e26475. doi: https://doi. org/10.18471/rbe.v32.26475

17. Bonvicini KA. LGBT healthcare disparities: What progress have we made? Patient Educ Couns. 2017;100(12):2357-61. doi: https://doi.org/10.1016/j. рec.2017.06.003

18. Martínez-Guzmán A, Îñiguez-Rueda L. Discursive practices and symbolic violence towards the LGBT community in the university context. Paidéia. 2017;27(suppl.1):367-75. doi: https://doi. org/10.1590/1982-432727s1201701 
Peixoto MF, Conceição VM, Silva SED, Santos MA, Nascimento LC, Araújo JS

\section{- Authorship contribution:}

Myllena Ferreira Peixoto: conceptualization; research; writing - original draft; writing - revision and editing.

Vander Monteiro da Conceição: formal analysis;

visualization.

Silvio Eder Dias Da Silva: writing - original draft; formal analysis.

Manoel Antônio dos Santos: formal analysis; writing -

review and editing.

Lucila Castanheira Nascimento: methodology;

supervision; writing - review and editing.

Jeferson Santos Araújo: conceptualization;

investigation; methodology; writing - review and

editing; project administration.

\section{- Corresponding author:}

Jeferson Santos Araújo

E-mail: jeferson.araujo@uffs.edu.br

Editor-in-chief:

Maria da Graça Oliveira Crossetti 